\title{
Franca Buffoni (1924-2011): a pioneer in biochemical pharmacology
}

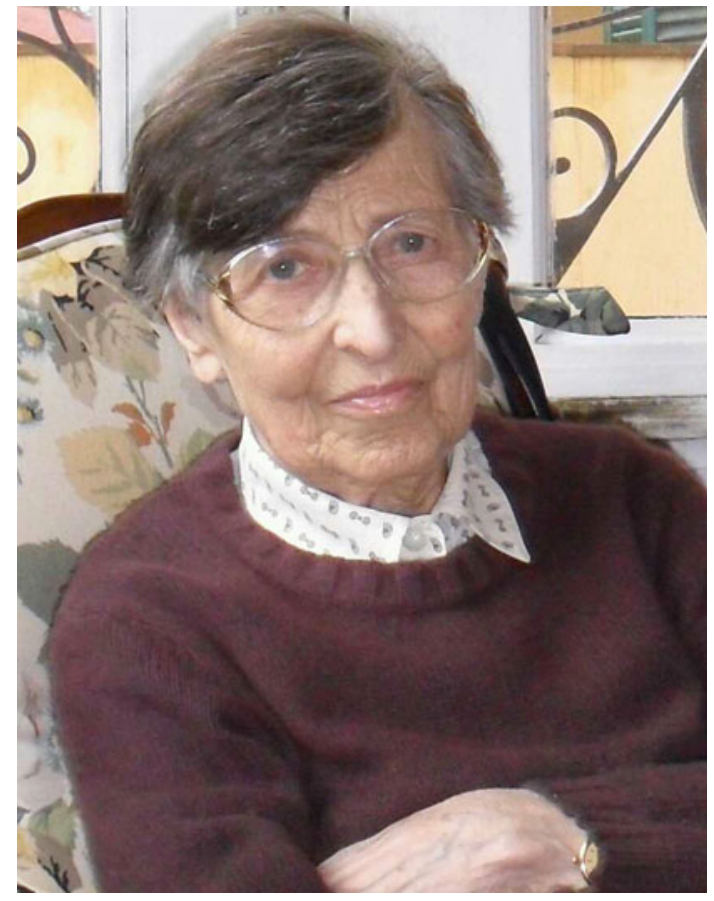

Franca Buffoni, Emeritus Professor of the Faculty of Pharmacy, University of Florence, Italy, passed away in her home after a short illness a year ago, on 1 November 2012, when she was 87 years old.

She was generally acknowledged as one of the pioneers in the field of biochemical pharmacology. After graduating from the Faculty of Pharmacy at Florence University in 1947, she became Assistant in 1952, and was awarded the title of Reader (Libera Docenza) in 1958. In 1970 she was appointed to the chair in Molecular Pharmacology, the first woman to obtain a chair in the field of Pharmacology in Italy. From 1971 to 1974, she was elected Dean of the
Faculty of Pharmacy of Florence University, only the second woman to be appointed Dean of a scientific Faculty in Italy at that time. Franca also served as Chairman of the Department of Preclinical and Clinical Pharmacology for a 3-year mandate, 1983-1985.

Her early scientific interests concerned the cardiovascular effects of natural compounds, particularly histamine and other endogenous amines. She was the first to hypothesize an important role of histamine metabolism in the effects of endogenous amines. This insight provided new perspectives in the pharmacology and development of histaminergic drugs. Following her mentor, Prof. Mario Aiazzi Mancini, she stressed the importance of chemistry and mathematics as the foundations of pharmacology and the necessity of the correct application of statistics in all phases of experimental work in pharmacology.

Since Franca was particularly interested in amine degradative enzymes, she spent the years 1962-1964 in Oxford at the laboratory of Prof. Hermann ("Hugh") Blaschko, an outstanding scientist who discovered amine oxidase in 1937 and had a particular interest in understanding the roles of physiological amines in relation to their biosynthetic and degrading enzymes. She left Florence, and her beloved family, arriving by train at Oxford, carrying a small but very heavy suitcase, and joined the lab as an unknown Italian postgraduate.

She found Blaschko to be a stimulating mentor with great knowledge and strong empathy. She committed herself with great enthusiasm to work on the purification and, possibly, the crystallization of the enzyme, benzylamine oxidase from pig plasma, a goal which she achieved in July 1963. From Oxford, in a letter of 21st July 1963 to her sister Piera, Franca discloses the feelings and emotions she 
went through in the struggle to go as far as to obtain the crystallization of the enzyme.

"Such a joy is born from the seriousness of my approach, the firmness of my character, the moral strength which did not allow me to give up in the face of difficulties. I have gone through terrible periods of waiting, tension, intensive reasoning to overcome difficulties, but I never lost confidence, as I always worked with logic, calmness, not aiming to succeed but for the joy of knowledge. In science you cannot have time or space limits, you proceed in the dark, not sure if you will be able to reach your goal within any imposed time limit. I understood this perfectly, and thus I did not know whether I could finish my task before the end of July. However, knowing this, I neither abandoned the problem nor worked faster. I worked as if I had an enormous amount of time, convinced that good work is of value even if not completed. I could see around me doubtfulness about the possibility of success, but within myself I always had an absolute trust in what I was doing. Such self-confidence made me go ahead. Everybody in the lab expressed admiration for the way I organized the work and the success of the various purification steps, but the actual crystallization was an unexpected fulfillment of a dream. Last week, achieving the crystallization was as if a bomb had exploded in Oxford, the first enzyme crystallized in this Department, the first histaminase crystallized in the world. I have been confused by so much fuss around me, I felt myself exposed and I understood that if one is not strong, success can be very damaging. But I was strong, I quickly went back to study my enzyme. This is only a step, albeit an important and wonderful one in the life of a scientist, which, nevertheless, necessitates continuation in the chosen path. Perhaps, it is the really great important step of my life. It answered my question whether I was really made for real science".

Hugh Blaschko was thrilled and proud of such an important achievement by Franca, but she found it confusing to have suddenly become a 'star', receiving the congratulations and handshakes of Oxford scientific academics, including the Nobel laureate Hans Krebs.

In the following months, she was torn between the offer to stay in Oxford with Blaschko and her University colleagues wanting to have her back in Florence. In 1964, after publishing her results in the Proceedings of the Royal Society in a joint paper with Blaschko, she took the decision to return to her home University in Florence. It was a difficult decision in which the strong affection she had for her family was a major influence. One can only speculate on the direction of her future career, had her decision been different. She continued her studies on benzylamine oxidase (also known as semicarbazide-sensitive amine oxidase or primary-amine oxidase), making a series of seminal observations on its behavior, functions and inhibitors.

In spite of her strong and continuing commitment to research and the great scientific success she achieved, she never confined her activities to the experimental work. Franca was equally committed to teaching; she was an excellent and passionate teacher, with the ability to transmit the enthusiasm, discipline and the rigor necessary to undertake experimental work to many generations of students. She was also able to express herself as an artist, dedicating much of her free time to painting.

She was a person of great integrity, always full of enthusiasm and drive for her special interests and also for the wider aspects of research. She was disciplined and focused in all she did, expecting the highest standards in herself and in those who worked with and for her. Her work was highly influential and many of those working in her field and related areas of pharmacology feel lasting gratitude for her insights and inspiration.

Laura Della Corte and Laura Raimondi, Florence. 